\title{
DỨcin
}

Technological University Dublin ARROW@TU Dublin

\section{Silent Stories of Resistance to Doing Employment}

Sue Mulhall

Technological University Dublin, Sue.Mulhall@TUDublin.ie

Follow this and additional works at: https://arrow.tudublin.ie/buschmanart

Part of the Business Administration, Management, and Operations Commons

\section{Recommended Citation}

Mulhall, S. (2013b) 'Silent Stories of Resistance to Doing Employment', Qualitative Research in Organizations and Management, 8(2): 181-200.

This Article is brought to you for free and open access by the School of Management at ARROW@TU Dublin. It has been accepted for inclusion in Articles by an authorized administrator of ARROW@TU Dublin. For more information, please contact arrow.admin@tudublin.ie, aisling.coyne@tudublin.ie, gerard.connolly@tudublin.ie.

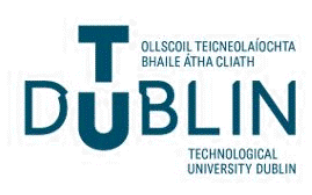




\section{Silent stories of resistance to doing employment}

\section{Resistance to doing employment}

Sue Mulhall

\begin{abstract}
Purpose - Exploring experiences of participants on an Irish active labour market programme, the purpose of this paper is to examine accounts of everyday forms of resistance to the subject positions offered in the dominant discourse of "doing employment" espoused on such schemes.

Design/methodology/approach - Employing narrative research, the process of individual opposition to established work routines is illustrated at the level of meaning, identity and selfreflection by using the three-dimensional narrative inquiry space to chronicle three participants' stories. Their newly formed subjectivities (created by changes encountered in their past lives and the situations they are experiencing in their present realities) challenge the power of the dominant discourse of 'doing employment' on these schemes. The paper illustrates how the individuals respond when confronted with feelings of difference between the subject positions offered within the dominant discourse and their own preferred interest.

Findings - Their stories suggest different forms of micro-political resistance, from subtle acts and behaviours through to contesting subjectivities and meanings. The article describes how they exercise power in imposing their own meanings through challenge and reinscription, thus rendering the dominant discourse less robust. This creates space for further challenge and reinscription, possibly enabling others to think differently, such as the author, who has moved from unquestioning acceptance of the dominant discourse to an emerging micro-political resistance to "doing employment".

Originality/value - These accounts highlight the relevance of using narrative research to reveal, heretofore, silent stories of how individual work routines disrupt prevailing institutional discourse, depicting situations where a story by challenges a story of.
\end{abstract}

Keywords Micro-political resistance, Doing employment, Narrative inquiry, Employees attitudes, Narratives

Paper type Research paper

\section{Introduction}

Dominant discourse of "doing employment"

Discourse constructs a topic, defining and producing the objects of our knowledge. It governs the way that topics can be meaningfully talked about and reasoned about, and influences how ideas are put into practice and used to regulate the conduct of others (Foucault, 1976/1978, 1975/1979, 1980, 1982). Take employment. The identification of the employment experience with paid work has been observed by a number of commentators (see, e.g. Bauman, 1999; Coakley, 2004; Collins et al., 2010; Taylor-Gooby, 1991). This association is epitomised in the dominant discourse of employment, whereby the primary means of securing a livelihood is through engagement in the formal labour market (Bauman, 1999). The ultimate intention of this action centres on "stimulating economic growth and development, raising levels of living, meeting manpower requirements and overcoming unemployment and underdevelopment" (International Labor Organization (ILO), 1964, p. 1). To achieve these objectives, countries are urged to pursue active labour market policies that directly support labour market (re)integration through the use of participation programmes (Auer et al., 2005; OECD, 2000, 2009). The paper is based on fieldwork carried out with participants employed on Ireland's principal active labour market programme, Community

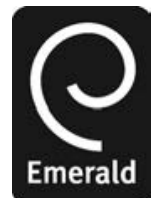

Qualitative Research in Organizations and Management: An International Journal Vol. 8 No. 2, 2013 pp. $181-200$

(C) Emerald Group Publishing Limited 1746-5648 
QROM

8,2

182
Employment (Hill and Halpin, 2008; O'Connell, 2002). This scheme aims to enhance the employability and mobility of the socially excluded, such as the long-term unemployed, invalidity claimants and other welfare recipients, by offering opportunities to partake in temporary work within their communities, whilst simultaneously availing of relevant education/training courses (FÁS, 2011). Within the domain of the dominant discourse of employment, paid work within the formal labour market is seen as the key to combating social exclusion (Bauman, 1999; Coakley, 2004; Collins et al., 2010; Lewis, 1992, 2001; Taylor-Gooby, 1991). There are a number of different discourses that mediate and find expression in this realm: a dominant discourse of normality, as represented by the employed; and a discourse of the abnormal, of the excluded, the unemployed who cannot obtain or retain a job (Coakley, 2004).

The article argues that unemployment can be considered in the same light as Foucault $(1975 / 1979,1976 / 1978,1980,1982)$ envisioned phenomena such as reason, madness, criminality and sexuality. For example, unemployment is not merely something that exists in the lives of the unemployed. It is through various techniques and procedures that unemployment is identified as a special object for knowledge, resulting in action such as the Community Employment programme whose objective is to (re)integrate the unemployed into the labour market. In this paper, Community Employment is conceived as a carceral network (Foucault, 1979), established with the aim of normalising the delinquent mindset of the unemployed, whose behaviour is undisciplined and potentially dangerous to normal society, so engagement on such a scheme is a form of rehabilitation.

The paper contends that participation on Community Employment entails "doing employment", paraphrasing West and Zimmerman's (1987) concept of "doing gender". They introduced the notion of gender as an accomplishment, that is, the product of daily social practices and behaviours that codify and manifest femininity or masculinity. "Doing gender" means to learn and perform complex societal activities of perception, interaction and micro-politics that define certain conduct as either feminine or masculine. Stressing the importance of social interaction in maintaining the gender structure, they claim that gender is visible in a wide variety of activities, such as conversation, appearance, mannerisms and body language. It is a socially required practice, and, therefore, a person cannot "not do gender", as her/his assigned sex category is imposed on her/him and is perceived as essential. In the context of Community Employment, this paper argues that by partaking on the scheme, participants display themselves as "individuals who have employment", simultaneously learning what it takes to be an "individual who has employment". "Doing employment" is unavoidable because of the social consequences of employment category membership, where we recognise ourselves as having the characteristics that locate us as members of various sub-classes of dichotomous categories and not of others (Davies and Harré, 2001), e.g. employed/unemployed. "Doing employment" renders the social arrangements based on employment category membership accountable as normal and accepted, that is, legitimate ways of organising social life. The institutional arrangements of a society can be seen to be responsive to the differences, the social order merely an accommodation of the natural order (West and Zimmerman, 1987), e.g. signing on to receive social welfare payments. Thus, if in "doing employment", employment is also doing dominance and unemployment is doing difference, the resultant social order, which supposedly reflects natural differences, is a powerful reinforcement and justification of hierarchical arrangements (West and Zimmerman, 1987). If we "do employment" appropriately, we 
simultaneously sustain, reproduce and render legitimate the institutional actions that are based on the employment category. If we fail to "do employment" appropriately, we, as individuals, not the institutional practices, may be called to account (Bauman, 1999).

\section{Micro-political resistance}

The paper highlights the progressive prominence of the dominant discourse of "doing employment" in the evolution of Community Employment in Ireland and explicates how this is sustained through the exercise of disciplinary techniques of normalisation (Foucault, 1979). This creates the potential for micro-political resistance, which arises from clashes between an individual's notion of self and the subject position offered in the prevailing discourse (Davies and Harré, 2001; Thomas, 2009). It challenges the dominant at the level of the individual, occurring where there is a space between the position of a subject offered by a discourse and personal interest (Weedon, 1997). The potential for such moments materialise during periods of change, as a person confronts and reflects on her/his role identity, recognising contradictions and tensions, and, in so doing, unsettle and subtly shift meanings and understandings (Thomas, 2009). The effects of such resistance are low levels of disturbance, weakening the hegemonic grip of established discourses, thus presenting opportunities to exploit gaps that enable the construction of alternative identities and meanings within forms of domination (Thomas, 2009). Similar to other studies (see, e.g. Thomas and Davies, 2005a), resistance is understood as a constant process of adaptation, subversion and reinscription of dominant discourses, occurring as individuals confront and consider their own identity performance, recognising inconsistencies and tensions (Thomas, 2009). It is an ongoing practice arising from the dual desire to know ourselves and to deal with the discord that arises from these contradictions. The paper conceives micro-political resistance as a form of institutional work where individuals engage in purposive action aimed at disrupting institutions, manipulating and ever transforming the institutional order.

\section{Theoretical contributions}

There is a dearth of studies exploring the understanding of Irish active labour market programme participants of their experiences on such schemes (Coakley, 2005), with a particular lack of research examining their everyday forms of opposition to the subject positions offered in the dominant discourse of employment. The paper bridges this gap by describing a narrative approach to comprehending the everyday modes of resistance and low-level misbehaviour enacted by three participants working on Community Employment. The process of individual defiance is illustrated at the level of meaning and identity by using the three-dimensional narrative inquiry space (Connelly and Clandinin, 2006) to analyse their career stories. The telling of these experiences facilitates identity (re)construction because narrating the self-changes the self (Bujold, 2004; Cochran, 1990).

In sharing three narratives, the aim is not to generalise the findings to a wider population. The objective is to gain an insight into the complex nature of how these individuals manage ambiguity when they reflect on their self following a period of discontinuity (Weick, 1995) in their employment experiences. As this triad have encountered unemployment prior to engaging on an active labour market programme, the paper argues that their experiences provide an excellent site for studying occurrences of micro-political resistance to the dominant discourse of "doing employment", as these moments potentially materialise during periods of change.

\section{Resistance to doing employment}

183 
QROM

8,2

184
The paper, therefore, is intended as a contribution to two academic fields. One addresses narrative constructions of identity and employment experiences (see, e.g. Bujold, 2004; Cochran, 1990), focusing on the effects of change when participants on an active labour market programme interpret their career stories (Coakley, 2005). By utilising narrative inquiry in this research site, the paper listens on the margins of society and gives voice to silent groups; silent because their stories and meanings have not been privileged, that is, previously told (Bates, 2004). The second contribution attends to micro-political resistance (see, e.g. Thomas, 2009; Weedon, 1997), using an active labour market programme as a place to study pockets of opposition to the dominant discourse of employment. This location is used because, as the participants are involved in a programme designed to (re)integrate them into the formal labour market (Auer et al., 2005; de Koning et al., 2001), they having previously experienced a period of discontinuity in their careers (Weick, 1995), thus providing potential opportunities for micro-political resistance.

In the analysis of these narratives a sub-plot unfolds: the author's questioning of the dominant discourse of employment on an Irish active labour market programme. After discussing the three participant's narratives, the paper concludes by recounting the author's journey from unthinking acceptance of this discourse to an emerging micro-political resistance to "doing employment". Chronicling how the author manages the potential chaos of this transition renders visible the largely invisible: the messiness involved in bringing worldviews to assembling, disassembling and reassembling stories from the field.

\section{Active labour market policy \\ International perspective}

Developing gradually over the twentieth century, the role of active labour market policy has undergone a fundamental transformation (de Koning et al., 2001; Hill and Halpin, 2008). During the Great Depression in the 1930s, measures to create jobs, such as the New Deal Programme in the USA, were introduced extensively. After the Second World War, a shortage of skilled labour due to the ravages of the conflict, combined with increased technological innovation, resulted in training for the unemployed in advanced automated production techniques, particularly in America and Britain. Active labour market policy, as an integral element of socio-economic policy, was first conceived and applied in Sweden, not as a response to widespread unemployment, but as a social democratic tool of macro-economic management to counter inflationary pressures resulting from full employment. The Swedish model was taken up by the OECD in the 1960s, with the organisation promoting active labour market policies designed to mobilise labour supply, improve the quality of the labour force using vocational training and augment the matching of vacancies and job seekers through enhanced placement and counselling services (OECD, 1964).

The sharp increase in unemployment throughout the advanced industrial countries in the aftermath of the first oil price shock in 1973 revealed marked changes in labour market relationships, as mass unemployment and slow growth coincided with rapid inflation (Auer et al., 2005; Hill and Halpin, 2008). Initial actions to counter unemployment were based on the assumption that the problems were cyclical, and, therefore, temporary, thus, there was a shift in labour market policies to demand side measures. These included wage subsidies to stimulate the demand for labour, as well as promotion of early retirement to reduce labour supply, and, by the 1980s, temporary direct job creation schemes to absorb surplus labour. 
The persistence of soaring unemployment, however, even during the expansionary periods of the 1980s triggered a realisation that high unemployment and other labour market problems was neither temporary nor simply due to insufficient demand. In the 1990s, this resulted in a further policy change based on the premise that structural market difficulties were primarily on the supply side, generating a renewed emphasis on earlier strategies to mobilise labour supply (Auer et al., 2005; de Koning et al., 2001; Hill and Halpin, 2008). This move was reflected in the OECD's recommendations, with the organisation proposing a transfer of labour market expenditures from passive measures that provide protection for unemployed workers, to active programmes that mobilise labour supply, develop the skills of the labour force and strengthen the job search process (OECD, 1993).

From the 1990s onwards, governments have viewed active labour market policy as a means of ameliorating unemployment, especially long-term unemployment. Unemployment is perceived as a major cause of poverty and social exclusion (de Koning et al., 2001; OECD, 2009). The prevention of long-term and recurrent unemployment, therefore, is considered a major contribution towards combating poverty and social exclusion (de Koning et al., 2001; Spicker, 2008). Active labour market policies are, consequently, recognised as important tools in combating social exclusion by reducing unemployment, particularly long-term unemployment (de Koning et al., 2001; Spicker, 2008).

\section{Irish perspective}

Community Employment is Ireland's foremost active labour market programme (Denny et al., 2000; Layte and O'Connell, 2005; O'Connell, 2002; OECD, 2009). It is a direct job creation scheme with the dual purpose of facilitating participants to re-enter the formal workforce by breaking their experience of unemployment through a returnto-work routine, and supporting access to programmes, services and employment for individuals experiencing social exclusion (FÁS, 2011).

Within Community Employment, there are a number of stakeholders: FÁS, the country's training and employment authority, who operated the scheme at the time the paper's research was conducted, but these programmes now come within the remit of the Department of Social Protection (FAS, 2011); sponsor organisations, such as community groups and not-for-profit companies, who employ the participants; and the participants, who work in the sponsor organisations and augment their skills through targeted training (FAS, 2011). Each participant works 39 hours per fortnight, usually performing their duties in a $19 \frac{1}{2}$-hour week. Their responsibilities are contingent upon the exigencies of the sponsor organisation's business, such as a caretaker or receptionist in a community centre. The participants have individual learner plans that support their development through the acquisition of formal certification and the attainment of specific work-related competencies achieved on-site, aimed at acquiring active employment and/or further education/training (FÁS, 2007). They are paid weekly by the sponsor, with the state offering grants towards the cost of employment. When this paper's research was undertaken, some participants had a dual entitlement to both social welfare benefits and to Community Employment remuneration, such as those receiving invalidity-related payments; a situation that no longer prevails (Department of Finance, 2011).

It has been contended that Community Employment shares many characteristics of a social inclusion scheme, rather than a labour market activation programme (National Competitiveness Council (NCC), 2010). This is, perhaps, not a surprising assertion because, as previously mentioned, such policies are now perceived as an important tool 
$\mathrm{QROM}$

8,2

186 in combating social exclusion by reducing unemployment (Spicker, 2008). Chronicling the development of Community Employment reveals that the goal of social inclusion has become progressively underpinned by the dominant discourse of employment. This can be observed when the objectives and language espoused by FÁS, from the early stage of the scheme's development through to contemporary times, are examined. The stated aim of the Social Employment Scheme, the predecessor to Community Employment (1984-1994), was to "help the large number of productive and energetic persons who have been unemployed for an extended period to make their contribution to social and community development" (Duggan, 1999, p. 3). It was not originally designed to place people in permanent employment or to progress them into education/ training (Duggan, 1999). In 1999, FÁS maintained that due to the changed nature of the labour market, it had to adopt an innovative approach to ensuring an adequate supply of labour for the "booming Irish economy" (FÁS, 1999, p. 14). A review by FÁS in 2002 concluded that there was a requirement to increase the focus on helping individuals progress to "normal employment" (FÁS, 2003, p. 12). Four years later, the aim of Community Employment was to enhance the employability and mobility of disadvantaged and unemployed persons by providing opportunities for them to engage in "useful temporary work within their communities" (FÁS, 2007, p. 20). By 2008, Community Employment emphasised the "integration/re-integration into the labour market of long-term unemployed and other marginalised people" (FÁS, 2008, p. 19), a goal that is still pursued (FÁS, 2011). Over two decades, the objective of social inclusion in Irish active labour market policy has explicitly become secondary to economic exigencies. This subordination of social inclusion aims to goals of economic growth, whereby social policies are utilised to manage the economy, has been recognised as a feature of Irish public policy, including labour market policy, by numerous commentators (see, e.g. Coakley, 2004; Collins et al., 2010).

\section{Methods}

Background

This study is part of a wider inquiry concerned with the career stories of 27 participants from seven different Community Employment Schemes in Ireland. The personal profiles of the respondents are: 24 women and three men, spanning a range of ages; 26 are white Irish and one is an Irish traveller, an individual belonging to the class of persons who traditionally pursue, or have pursued, a nomadic way of life (Coakley, 2004); 17 are single; 20 of them have at least one child; they have achieved various levels of educational attainment; and represent a variety of socio-economic backgrounds.

The main analysis explores how these participants construct, interpret and make sense of their career experiences. A consensus seems to have emerged that the established description of career is "the unfolding sequence of any person's work experiences over time" (Arthur et al., 1989, p. 8). Using theoretical sampling (Flick, 2009) and employing a narrative research strategy, the study collects its empirical data through episodic interviews. The relevance of narrative inquiry for careers research is its ability to assist people to make sense of, and to reflect on their career experiences, decisions and transitions, in addition to facilitating a consideration of the temporal and developmental aspects of a career (Bujold, 2004; Cochran, 1990).

\section{Methods}

Narrative research privileges living experience, allowing an inquirer to understand and make meaning of events in a person's life through their stories (Clandinin and Connelly, 
2000; Clandinin and Rosiek, 2007; Connelly and Clandinin, 2006; Flick, 2009; Gabriel, 2004). It assumes that storytelling is integral to comprehending lives, and that people form narratives as a process in constructing and reconstructing their identity (Clandinin and Rosiek, 2007). Individuals interpret events in the stories they construct collaboratively with listeners (Bujold, 2004). Narratives are, therefore, a discursive resource used to make sense of experience, including the meaning of the self and relationships with others (Gabriel, 2004). Identities are thus produced in the stories that people tell about themselves (Langellier, 1989). Self-identity is constituted as actors attempt to configure a coherent, continuous biography where their life-story is the sensible result of a series of related occurrences or cohesive themes (Cochran, 1990).

The life of an individual, however, cannot be adequately appreciated without reference to the institutions within which her/his biography is enacted because much of human existence consists of playing roles within these entities (Clandinin and Connelly, 2000; Mills, 1959). Narratives are structured, socialised and politicised by institutional and cultural conventions, such that actors can only choose from the broader cultural collection of discursive resources (Goodley et al., 2004). They can, therefore, be conceived as political praxis, raising questions about relations among power, knowledge, ideology and identity (Langellier, 1989). Consequently, narratives produce ways of seeing the world that privilege certain discourses and meanings over others. People, however, create a range of narrative strategies in relation to their discursive environments, that is, individual stories are constrained, but not necessarily determined, by discourses (Langellier, 1989). Narrative research, as a discursive resource, offers ways to interrogate the practices by which subjects are constituted (Alvesson and Sköldberg, 2009; Thomas, 2009). It assists in the understanding of the dynamics of identity regulation and resistance in contexts of power and knowledge. Power and knowledge are parallel concepts that serve as dialectically reinitiating practices, which both assist and limit a range of social practices, with knowledge inextricably enmeshed in relations of power because it is always being applied to the regulation of social conduct in practice (Foucault, 1975/1979, 1976/1978, 1980, 1982). The analysis of the participants' narratives is framed within a conceptualisation of identity that is fluid, fractured and reflexive (Giddens, 1991), its construction being stimulated by social interaction and ordered by institutionalised patterns of being and knowing. Viewing identity in this manner facilitates a focus on the operation of power relations where power is expressed in various micro contexts (Foucault, 1975/1979, 1976/1978, 1980, 1982), thus providing opportunities to study micro-political resistance (Thomas, 2009).

As this broader inquiry explores the career experiences of Community Employment Scheme participants, the episodic interview, a narrative technique, is deemed an applicable modus operandi (Flick, 2009). The episodic interview yields context-related presentations about particular experiences that the interviewee remembers in the form of a narrative (Flick, 2009). It invites respondents to tell stories that are meaningful to them and is often utilised in situations where interviewees may have difficulty responding to a formal line of questioning (Bates, 2004). Episodic interviewing is, therefore, relevant for studies researching marginalised members of society, whose stories have not been previously privileged, such as participants on active labour market programmes.

The interviews were conducted at the participants' workplaces using an interview guide designed to orient the discussion to the topical domains under consideration, that is, career experiences. The meetings were tape-recorded with the participants'

\section{Resistance to doing employment}

187 
$\mathrm{QROM}$

8,2

188 permission and subsequently transcribed verbatim. The average length of an interview emanating from the main study was 38 minutes, with a range of 20-60 minutes. Regarding the three stories spotlighted in this paper, the average was 42 minutes, with a range from 33 to 51 minutes.

\section{Analysis}

Analysing episodic interviews necessitates restorying the original data, which involves reading the transcript, interpreting it to understand the living experiences and then retelling the story (Flick, 2009). The three-dimensional narrative inquiry space (Clandinin and Connelly, 2000; Connelly and Clandinin, 2006) is an approach for restorying field texts, paying attention to temporality, place and sociality, thus providing rich detail about the context of the participant's life (Clandinin and Rosiek, 2007). These keystones concern the events and experiences in a person's narrative according to the timeframe in which they occurred (temporality), the significant settings in which they happened (place), and the personal and social resources utilised during these events and experiences (sociality).

Having collected the stories from the 27 participants, the approach to data analysis was to work through the narratives interpretivistically, restorying each experience individually and then collectively in a two-stage thematic coding procedure (Flick, 2009). Step one comprised restorying their careers by charting their experiences onto the cornerstones of the three-dimensional narrative inquiry space, including outlining their perceptions of their current status, as participants on Community Employment. Step two entailed classifying the themes linked to the single cases by plotting the respondents' response strategies to the change experienced in their careers, following a period(s) of unemployment and subsequent engagement on an active labour market programme. A common feature surfaced in the analysis: all of the informants viewed participation on Community Employment as a critical moment in their lives, triggering and facilitating processes of self-reflection and transformation (Eräranta et al., 2009; Giddens, 1991). It revealed how the participants created their narrative strategies in relation to their discursive environments, how their career stories were facilitated or inhibited by discourses, and how this impacted on their career identity.

To explore the usefulness of this approach in interpreting individual responses to participation on Community Employment following period(s) of long-term unemployment, three stories are examined more closely (Aaron, Maura and Zach). These accounts are the only chronicles from the main analysis $(n=27)$ that demonstrate evidence of opposition to the dominant discourse of "doing employment" on the scheme; the other 24 stories indicate an unquestioning acceptance of this discourse. The three narratives highlight the potential for micro-political resistance, revealing clashes between an individual's notion of self and the subject position offered in the prevailing discourse (Thomas, 2009); what this author terms micro-political resistance to "doing employment". Their stories draw attention to how resistance is stimulated by the incongruities, weaknesses and gaps between alternative subject positions (Thomas and Davies, 2005a).

\section{Three narratives \\ Introduction}

This section explores the ways in which three participants, whilst partaking on Community Employment, engage in micro-political resistance by producing 
alternative forms of power/knowledge (Foucault, 1975/1979, 1976/1978, 1980, 1982) to the acceptable modes of existence espoused by the dominant discourse of "doing employment". Their narratives are analysed using the three-dimensional narrative inquiry space (Connelly and Clandinin, 2006) and their response strategies to engaging on the scheme following long-term unemployment (micro-political resistance to "doing employment") is incorporated in to their stories. Adopting this approach stresses forms of understanding that they create of themselves, their lives and their careers. During the restorying of the narratives, attention is paid to commentary, as told by the participants, illustrating key moments in their employment/unemployment experiences, particularly the existence of micro-political resistance.

\section{Aaron's story}

Temporality. As a 53-year-old married man, with three grown-up children, Aaron has spent the majority of his career working as a qualified carpenter interspersed with periods of unemployment. He also held a maintenance position on a health farm for two-and-a-half years and is now on Community Employment for the second time, employed as a caretaker in a community centre. Aaron is on the scheme because he feels less pressure to earn money due to his changed family circumstances, as his children are self-sufficient and his wife is working part-time.

Place. The environment that impacts on Aaron's career is the type of location where he worked for 35 years, a building site. Here he learned the technical knowledge of his trade, becoming proficient in his carpentry profession. As a young apprentice, Aaron was socialised into the norms and behaviours of working on a construction site by a seasoned colleague. He acknowledges the importance of acquiring both occupational skills and behavioural standards at this stage of his life, recognising that it influenced him for the rest of his career:

He showed me how to behave, how to work and how to behave when I'm working. [...] He would have been probably an influence.

Sociality. Aaron predominantly narrates his story in the first person, exhibiting a strong feeling of responsibility for both himself and his family. His sense of obligation to financially provide for his family is evident in a tale that he tells about earning extra money during the recession of the 1980s in Ireland, chopping logs and selling the sticks house-to-house one Christmas. Aaron works for money to support himself and his family and considers that his time working on building sites was the most successful part of his career, as he earned the greatest income during that period. Reflecting on his jobs, Aaron does not believe that he has had choices, either now or in the past. He was told by his father to leave school at age 15 to become a tradesperson, and, when working as a carpenter he regards that the uncertain nature of the building industry, combined with his family responsibilities, resulted in him taking whatever position was on offer. Aaron still feels that he has no options, believing that there are few jobs available to him because of his age and the current recession in Ireland:

I think anyone over 50 now is going to have a problem getting any kind of work.

Micro-political resistance to "doing employment". What Aaron believes is a "no-questions" culture is prevalent in the Community Employment system. He indicates a desire to secure a wage, which is the primary reason that he is engaging on the scheme. To supplement this, Aaron works in the informal economy, not declaring his earnings to the revenue, a practice that is illegal. According to him, it is easier to

\section{Resistance to doing employment}

189

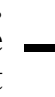


QROM

8,2 make additional money in the informal economy when working on the scheme, as opposed to doing so while claiming social welfare only, because fewer questions are asked:

If I have a chance of getting a bit of work on the Scheme no-one can actually say: "right, you're signing and working". [...] Whereas, if I was on the dole and I was caught working on the dole, you're going to be done.

\section{0}

\section{Maura's story}

Temporality. Maura is a divorced woman in her early 50s, with two grown-up daughters. Her story reflects three distinct phases of her life: working as a bookkeeper; a critical episode in her life involving a marital breakdown, followed by a nervous breakdown; and subsequent participation on Community Employment. The majority of Maura's working life was spent as a bookkeeper with one company (a clothing retailer). She constantly describes her sense of fulfilment in carrying out her duties there and the status she felt attached to that position. Following the dissolution of her marriage, Maura had a nervous breakdown and it took four years to piece her life back together. For the past two years, Maura has been employed on Community Employment, as a receptionist in a parish centre.

Place. The setting of significance in Maura's career is a structural one; the Community Employment(CE) Scheme. She is scathing about the programme, deriding both the position that she occupies and the system that facilitates what she perceives as a meaningless role:

The $\mathrm{CE}$ things are Mickey Mouse. [...] There's no value for me. It's not taking me anywhere. Sociality. Maura comes across as a self-aware individual, a skill possibly heightened by her participation on the Alcoholics Anonymous 12-step programme following her successful recovery from alcoholism two decades ago. An example of this selfunderstanding is a story that she narrates about how she consciously changes her accent to complement the roles that she operates in. In her bookkeeping job, Maura claims that she was highly successful and felt in control of her career. On Community Employment, in contrast, she feels that she is employed in an insignificant job in a worthless system, only working for money. Maura does not believe that she has control over her career, as she must remain within the welfare system to earn sufficient funds to survive:

It's only for money. [...] It suits me to be staying inside the welfare system.

Micro-political resistance to "doing employment". According to Maura, participants on the scheme are involved in a state-sponsored welfare scam, legitimately defrauding the system by partaking in futile programmes. She is aware of her own contradictory position; notwithstanding that she considers it a con, she is still involved with it. Maura's Janus faced approach is legitimised by her: she does not value the scheme, so she "skives" off; she witnesses other people "skiving off", so it is not a personal abuse of the system, but a structural issue; and she needs the money that the programme provides, so is working in a system that she does not revere. Maura participates on Community Employment to maximise her monetary return, that is, to claim invalidity benefit in addition to payment for engaging on the scheme:

There's a stigma attached to $\mathrm{CE}$ and to welfare [...] like, we steal from the system, like fraudsters. Technically I'm not a fraudster, technically by law I'm not, but in my head I am. [...] I disrespect it obviously. I use it obviously, but as far as I can see, that is the structure of it. 
Temporality. Zach is a separated traveller, in his early 40s, with three children from his first marriage and three children from his second relationship. He narrates his story over three chapters: currently partaking on Community Employment as a caretaker in a community centre; preceded by an extended phase of unemployment (18 years); and working in paid employment for less than eight years. These eight years included retail work, participating on state-sponsored training schemes for travellers and employed as an operative in a manufacturing facility. The 18-year period of unemployment coincided with his first marriage, the subsequent termination of that relationship, alcoholism, starting a new relationship and recovering from alcoholism. Now on Community Employment, Zach has made no plans, hoping to remain on the scheme for as long as possible.

Place. The location that influences Zach's career is the area where he grew up. Being brought up in a wealthy suburb in Dublin, Zach observes that people never realised that he was a member of the travelling community. This resulted in a mixed identity for Zach. He was part traveller, part settled person and part in-between:

As I come from [name of town], I was more or less classed 'traveller/settled person/in between'. I didn't know which way I was.

His first job was in a shop in his native village. With hindsight, Zach regrets leaving both that role and this locale at the age of 17 to go to Wales to live with his brother, describing the decision as a "mistake". Zach believes that if he had remained in that position, both his life and his career would have taken a more positive path. As he could not secure employment in Wales, he returned to Ireland, whereupon he met a woman with whom he subsequently had a failed marriage. This resulted in Zach ultimately losing his family and his possessions, and precipitated his alcoholism. He asserts that it was the wrong decision to leave his retail job in his local community, setting in train a sequence of negative events.

Sociality. The most significant aspect of Zach's persona, as it impacts on his career, is his alcoholism and ensuing recovery from it. Following the conclusion of his marriage, Zach started drinking "to forget". He drank heavily and consistently from 1994 to 2006, missing the maturation of his three children from his first marriage and being absent from key family and festive occasions. Since 2006, Zach has been sober. He recognises the role of personal and professional networks in triggering his recovery: meeting a new partner; living in a house in a settled community with his second family; witnessing the death of two close friends from alcohol abuse; and falling off his house roof, thus, subsequently, receiving medical assistance to "dry-out" while convalescing in hospital. With regard to his employment experiences, Zach always worked for money to acquire assets. In the early stages of his career, he claims that his earnings were used to fund his social activities, but, now, given his new family responsibilities, he utilises his income to pay for household bills and to buy presents for his children:

Getting a few bob and having it there for maybe things that you need, for the kids, birthdays, Christmas.

Micro-political resistance to "doing employment". The dilemma of Community Employment participation is referred to by Zach. He contends that he receives a double social welfare payment (Community Employment plus invalidity). To equal this amount from other sources, Zach maintains that he would have to work longer hours than the $19 \frac{1}{2}$-hour week permissible under the scheme. This explains his desire to 
$\mathrm{QROM}$

8,2

192 remain on the programme indefinitely, in contravention to the stated objective of Community Employment, to progress to mainstream employment:

If you go and get a job [...] for a 40-odd-hour week, you get the same money [...] as on Social Welfare.

\section{Discussion}

"Doing employment"

Aaron, Maura and Zach's stories depict three individuals standing at a "crossroads in their existence" (Giddens, 1991, p. 113): Aaron observes that his altered family circumstances permits him to partially discard the male breadwinner model (Lewis, 1992); Maura discusses how the dissolution of her marriage, and subsequent nervous breakdown, changed her career direction; and Zach talks about recovering from the ending of his first marriage and ensuing alcoholism. The disruption in the routines of their everyday lives (Giddens, 1991) culminated in engagement on an active labour market programme. Whilst partaking on Community Employment, the participants gain analytical skills through the scheme's personal development programme (FÁS, 2011), prompting critical self-reflection. During this process, the participants become cognisant of the institutional positions that contribute to their subjectivity and of the ways in which such practices both enable and constrain them (Eräranta et al., 2009).

Their revised understandings are evident in their everyday praxis (Thomas, 2009). Interpreting the observations of a concrete situation, the participants' experiences of Community Employment shows how the reality of the dominant discourse of "doing employment" is embodied in their daily routines and reaffirmed in social interaction (Emerson, 1970). What happens in the realm of employment is part of the common stock of knowledge (Berger and Luckmann, 1967), e.g. accepted norms of performance and behaviour and agreed mechanisms to deal with transgressions. For Community Employment participants, transitioning to the active labour market involves more than acquiring the skills to do the job. They have to learn how to behave in this locale, regulating their own actions and adapting to the behaviours around them (Van Maanen, 1977; Willis, 1977). Immersed in this world, the participant is guided through a potentially problematic situation in a contained manner (Emerson, 1970), moving from being unemployed to undertaking the day-to-day duties that an employee is expected to perform. Aaron illustrated this when explaining his caretaking role:

There's a drug clinic here on Tuesday and Thursday, so I have to be here to let the other girls go at five o'clock and that's on at 6:30. Then there's a computer class on in here tonight until 10 , so I have to be here until 10 tonight.

Participants are expected to partake in training to progress their careers (FÁS, 2011). There are, therefore, appropriate and inappropriate behaviours attaching to engagement on Community Employment, what can be termed "adjustment" and "maladjustment" (Mills, 1959, p. 102) or "normalcy" and "deviance" (Berger and Luckmann, 1967, pp. 124, 132). To maintain the reality of the dominant discourse of "doing employment", those who do not conform are "punished" and those who observe the conventions are "rewarded" (Willis, 1977, p. 67). For example, non-attendance at training virtually guarantees that participants' contracts will not be renewed, but involvement holds out the possibility of an extension. Maura describes feeling like an "outsider" (Van Maanen, 1977, p. 416), as she believes that she cannot involve herself in one of the crucial elements of the programme, training:

I'm very clever at computers [...] but you can't use them here because they want to be able to teach you something. [...] I just feel isolated, strange and different. 
The scheme, therefore, acts as a carceral network employing disciplinary techniques of normalisation (Foucault, 1979), whereby a range of mechanisms are formulated and directed to produce self-controlled individuals (Chriss, 2007). This is achieved by creating differences between employment and unemployment, that is, between the paid work experience (as represented in the notion of employment) and all other experiences (characterised by unemployment). Once these disparities are constructed, they are used to reinforce the "essentialness" (West and Zimmerman, 1987, p. 137) of employment. Unemployment is, therefore, identified as a special object for knowledge (Foucault, 1975/1979, 1976/1978, 1980, 1982), resulting in action such as confinement (participation on Community Employment) and different treatment (receiving benefits/sanctions for fulfilling/challenging the conditions to progress to the active labour market). The very act of involvement on the scheme, a seemingly voluntary activity, is rewarded by the dual payment; being remunerated for participation, in addition to retaining social welfare payments. In a carceral network, these normalisation processes are applied to ever-expanding groups of persons (Chriss, 2007). This is evident in the broadening of the types of people eligible for Community Employment over time, which now includes lone parents, members of the travelling community and people with disabilities (FÁS, 1999, 2011). The continuing extension of the categories deemed to be socially excluded is indicative of the supremacy of the goals of economic growth (Collins et al., 2010), whereby the socially excluded are represented as the "other", the dependant (Coakley, 2004). The ensuing policy responses are primarily developed to counter the social "problems" associated with the growing categories of people who are represented as "different" and a "burden" on the rest of society (Christie, 2004), that is, the maladjusted (Mills, 1959) and the deviants (Berger and Luckmann, 1967). This reflects the Foucaultian notion of what we think we know in a particular period has a bearing on how we regulate, control and punish (Foucault, 1975/1979, 1976/1978, 1980, 1982).

\section{Resistance to "doing employment"}

Aaron, Maura and Zach's micro-political resistance to contesting these normalisation techniques is aimed at precisely where power resides - in action - generating low levels of disturbance (Thomas, 2009). They present a "quiet challenge" (Thomas et al., 2004 , p. 7) to the accepted form of "doing employment". Their subject positions emerge as they reflect on their "self" during a time of change, considering the subjectivising forces of the dominant discourse of employment (Thomas and Davies, 2005a). This deliberation plays a part in the emergence of new forms of thought, or at least novel ways of working with existing categories and concepts that the prevalent cultural systems of representation sanction as normal and desirable (Eräranta et al., 2009) when "doing employment". Their stories suggest a variety of forms of micro-political resistance to the "essentialness" (West and Zimmerman, 1987, p. 137) of "doing employment", from subtle deeds and behaviours through to challenging subjectivities and meanings (Thomas and Davies, 2005b). The narratives display examples of such acts of resistance. Aaron works in the informal economy whilst participating on Community Employment, an illegal practice. He believes that there is a stigma connected with claiming social welfare payments without actually working for the money, but does not perceive any contradiction in simultaneously engaging in both Community Employment and the informal economy. "Working for his money" on the

\section{Resistance to doing employment}

193 
$\mathrm{QROM}$

8,2

194 scheme, that is, a legal endeavour, allows him to justify "doing a nixer", an illegal activity, to generate additional monies for himself and his family:

I could do the bit of work, plus I'm off the dole. I don't want to be on the dole [...] the stigma of it [...] it's what's in your pocket at the end of the day that makes all the difference.

Maura does not partake in training, an integral component of the scheme. This non-participation is manifest when she compares her former working life as a bookkeeper with her current situation on Community Employment. Acknowledging the competence and competencies displayed in her previous role, Maura now perceives these skills as disadvantageous, rationalising her lack of engagement in training by referring to the culture of "skiving off" on Community Employment:

I was very successful for 30 years [...] Now I sit in that bloody reception box and play on the internet. [...] I think for them it would be hard to find something to actually teach me. Where the quality of being able to learn a skill was of benefit before, now it's a redundant quality. $[\ldots]$ To be a little bit educated even, it's a drawback [...] That is all part of it, skiving off. I do it, other people do it. When I was in real work, that didn't happen me; I wouldn't think of it.

Zach makes no plans to (re)enter the active labour market, as working a $19 \frac{1}{2}$-hour week on Community Employment is financially more lucrative than occupying a full-time position in mainstream employment. His lack of career planning is a recurrent theme, but what differentiates his practice now from previous situations is his belief that the system itself facilitates such a strategy. Recognising this paradoxical position, Zach feels constrained by the structure of Community Employment compared to the active labour market; a milieu to which he is supposed to transition to:

Your hands are tied behind your back [...] You get $€ 365$ and another $€ 26$ [...] if you go and get a job you get the same thing.

Resistance is observable in all three narratives, occurring in the space between the position of a subject offered by the dominant discourse "doing employment" and personal interest (Weedon, 1997), encouraging these individuals to engage in purposive action aimed at disrupting the institutional order (Thomas, 2009).

At the discursive level, an emphasis on "being different" is a form of defiance in its own right, with these participants distancing themselves from aspects of the dominant discourse of "doing employment", whilst exploiting or subtly subverting meanings and subjectivities offered within it (Thomas and Davies, 2005b). Maura, in particular, is not only resisting in her acts and behaviours, but also through how she negotiates and redefines the meanings associated with "doing employment" on an active labour market programme. For example, the contradictory positions of central government departments, which create an anomalous situation for Community Employment participants is rarely highlighted in the Irish employment discourse. According to the Department of Social Protection, a person is on invalidity benefit because she/he is unable to work, but individuals claiming this allowance, and simultaneously partaking on the scheme, are actually encouraged by the Department of Jobs, Enterprise and Innovation to seek formal employment. Maura succinctly summarises this incongruity:

I'm on invalidity pension because I'm not capable of working, but I'm on CE to get me back to work.

Resistance as reflexive practice

These three participants are adapting and/or drawing on alternative subjectivities to those advanced by the dominant discourse of "doing employment". Challenging a 
subject position involves relying on a substitute or subverting the original, in a process of reinterpreting the prevailing orthodoxy (Thomas and Davies, 2005b). Resistance is, therefore, not only oppositional to the subjectivity proffered, but also a critical and generative reflexive practice (Thomas and Davies, 2005a,b). Resistance can be appreciated at the level of identity and in the conceptualisation of meanings of everyday practice (Thomas and Davies, 2005b). Watson (2008) suggests that through personal identity work actors can influence, within limits, the various institutionally prescribed social identities that pertain to them. This study uncovers some of the micro-mechanisms through which this may be possible, explicating the micro-processes that marginalised persons can utilise to resolve the experience of institutional contradictions, thereby possibly affecting the ways institutions are reproduced at the individual level (Thomas and Davies, 2005a).

Central to their stories is identity work triggered by the experience of personal change. Identity work has internal and external aspects, projecting both inwardly and outwardly as individuals have scope to interpret or even modify the roles given to them in institutional scripts (Watson, 2008). These three stories suggest that the disruptions to the routines in their everyday lives (Berger and Luckmann, 1967), which triggered participation on Community Employment, represent the inward aspect of identity work. Their micro-political resistance to "doing employment" whilst engaging on the scheme characterise the outward aspect, as it involves behaviours that are visible to others. Evident in Aaron's story is the shedding of his male breadwinner identity, which, for him, affords new-found freedom. Over the years, feeling the onus of responsibility to financially provide for his family prompted him to work in the highly paid, but insecure construction industry. Now, with his wife working part-time, and his children virtually economically independent, he receives a consistent, but relatively low income from Community Employment, supplemented by monies earned in the informal economy. For Maura, her identity is associated with her employment status. In describing her former bookkeeping role, she represents herself as the "leader of the pack", describing her confidence in her capacity to perform her role and the sense of self-worth that contributing to a successful business engendered for her. A contrasting picture is painted when Maura sketches her current situation; drawing attention to how she disrespects herself for partaking in what she believes is a worthless job. Zach discusses how he had been confused with his ethnic identity in the past (traveller), and how that lifestyle impacted negatively on his ability to seek and retain employment. Now, living in a settled community, following recovery from alcoholism, he is able to search for, and secure, a place on Community Employment, albeit with no definite career plans. Their stories reinforce the contention that, in times of discontinuity, when boundaries begin to dissolve, established patterns become less appropriate as guides for action, and, simultaneously, revised interactions become more habitualised, as people adapt their behaviour to cope with ambiguity (Weick, 1995).

The stories support the final phase of Foucault's thinking about the self, where the subject actually functions as a pocket of resistance to established forms of power/ knowledge (Foucault, 1988). In this late Foucaultian version of subjectivation, these three subjects are not primarily a social construction, but a construction of the selfreflecting on the self, albeit a creation that established forms of power/knowledge continually try to imprint with their own crystallised patterns (Alvesson and Sköldberg, 2009). For the participants, the construction of the self-reflecting on the self encourages them to challenge the dominant discourse of "doing employment". This is facilitated by training provided on Community Employment, which occurs in tandem

\section{Resistance to doing employment}

195 
QROM

8,2

196 with the scheme applying normalisation techniques to produce self-controlled individuals (Chriss, 2007) "doing employment".

Individual dissent through identity work can also contribute to destabilising truths. The resistance that the participants exhibit affords the possibility to influence the accepted mode of "doing employment". The author's research story illustrates how those engaging in identity work can potentially use their institutional roles in ways that challenge institutional prescriptions. At the commencement of the study, this author's taken-for-granted assumption (Berger and Luckmann, 1967) of the purpose of Community Employment was to assist participants to (re)enter the labour market, a belief influenced by the dominant discourse of employment. Upon conclusion of the study, the author queries this perspective, now viewing the scheme as society's conceptual machinery designed to maintain the official universe of employment against the challenge of unemployment with participation on the scheme re-socialising the unemployed into the objective reality of the symbolic universe of society (Berger and Luckmann, 1967). This transformation is prompted by Aaron, Maura and Zach's stories, in tandem with newly acquired knowledge gained researching active labour market programmes, highlighting the "ambiguities, complexities, difficulties and uncertainties" associated with narrative inquiry (Clandinin and Connelly, 2000, p. 55). Cognisant of how this conversion could potentially influence the analysis, the narratives have been listened to carefully, literally and figuratively, to ensure that the participants, not the author, play the lead role, with their words placed centre stage. In representing their narratives, the author has been particularly attuned to voices that make visible and audible accepted practices, processes and features of our everyday social world. Relating the author's story underscores how not only do we "bring the self to the field [...] [we also] create the self in the field" (Reinharz, 1997, p. 3).

In summary, this paper describes how participants from a traditionally silent milieu in research terms exercise power in imposing their own meanings through challenge and reinscription. In doing so, they render the dominant discourse of "doing employment" less robust and unified, creating space for further challenge and reinscription, enabling others to begin thinking and behaving differently (Thomas and Davies, 2005b).

\section{Conclusion}

These accounts highlight the relevance of using narrative research to reveal, heretofore, silent stories of how individual work routines disrupt prevailing institutional discourse because they depict situations where "a story by challenges a story of" (Goodley et al., 2004, p. ix). Narrative inquiry provides a vehicle to critically understand the means through which the prevailing institutional discourse can be resisted at the micro level. The process of individual opposition to established work routines is illustrated at the level of meaning, identity and self-reflection by using the three-dimensional narrative inquiry space to chronicle the stories of three participants on an Irish active labour market programme. Their newly formed subjectivities, created by a combination of the changes they have encountered in their past lives and the situations that they are experiencing in their present realities, are challenging the power of the dominant discourse of "doing employment" espoused by the scheme.

The paper contributes to the development of a more detailed understanding of the study of the silent stories of people's individual work routines disrupting institutional practice in four ways. First, it presents a narrative conceptualisation of the 
micro-politics of resistance, focusing on how previously voiceless participants on an active labour market programme articulate their accounts of processes of work resistance, reproduction and reinscription to the dominant discourse of "doing employment". Second, by drawing on specific cases of individuals engaged in the act of critical reflection on their experiences of employment/unemployment, the paper illustrates the practice of this resistance, portraying how and in what ways the individuals respond when confronted with feelings of difference and discomfort between the subject positions offered within the dominant discourse and their own preferred interest. Third, by focusing on the living experiences of the participants, it offers an empirically grounded, critical understanding of the character and conduct of the dominant discourse of "doing employment" with greater nuance than that currently found in the literature, examining how the dominant discourse of "doing employment" is created, maintained and disrupted. Finally, by explicitly incorporating the author's revised perspective with the discussion of the participant's stories, the view that material from the field is collected, analysed and rendered as a neatly ordered and presented package is dispelled. Telling the normally untold story of a researcher's journey emphasises the messiness and chaos sometimes underpinning narrative inquiry.

It is recognised, however, that there is a potential for further research: conducting a longitudinal study of the three individuals' stories; comparing and contrasting their narratives with the other 24 participants from the core study; and expanding the inquiry to include diverse geographical jurisdictions to examine the employment experiences of participants on other active labour market programmes.

\section{References}

Alvesson, M. and Sköldberg, K. (2009), Reflexive Methodology: New Vistas for Qualitative Research, 2nd ed., Sage, London.

Arthur, M.B., Hall, D.T. and Lawrence, B.S. (1989), "Generating new directions in career theory: the case for a transdisciplinary approach", in Arthur, M.B., Hall, D.T. and Lawrence, B.S. (Eds), Handbook of Career Theory, Cambridge University Press, Cambridge, pp. 7-25.

Auer, P., Efendioğlu, Ü. and Leschke, J. (2005), Active Labour Market Policies Around the World: Coping With the Consequences of Globalisation, ILO, Geneva.

Bates, J. (2004), "Use of narrative interviewing in everyday information behaviour research", Library \& Information Science Research, Vol. 26 No. 1, pp. 15-28.

Bauman, Z. (1999), In Search of Politics, Stanford University Press, Stanford, CA.

Berger, P. and Luckmann, T. (1967), The Social Construction of Reality, Penguin, London.

Bujold, C. (2004), "Constructing career through narrative", Journal of Vocational Behaviour, Vol. 64 No. 3, pp. 470-484.

Chriss, J.J. (2007), Social Control, Polity Press, Cambridge.

Christie, A. (2004), "Difference", in Fanning, B., Kennedy, P., Kiely, G. and Quin, S. (Eds), Theorising Irish Social Policy, University College Dublin Press, Dublin, pp. 147-164.

Clandinin, J. and Connelly, M. (2000), Narrative Inquiry: Experience and Story in Qualitative Research, Jossey-Bass, San Francisco, CA.

Clandinin, D.J. and Rosiek, D.J. (2007), "Mapping a landscape of narrative inquiry: borderland spaces and tensions", in Clandinin, D.J. (Ed.), Handbook of Narrative Inquiry: Mapping a Methodology, Sage, Thousand Oaks, CA, pp. 35-75.

Coakley, A. (2004), "Poverty and insecurity", in Fanning, B., Kennedy, P., Kiely, G. and Quin, S. (Eds), Theorising Irish Social Policy, University College Dublin Press, Dublin, pp. 112-127.

\section{Resistance to doing \\ employment}

197 
QROM

8,2

198
Coakley, A. (2005), "Mothers, welfare and labour market activation", Working Paper Series No. 05/04, CPA, Dublin.

Cochran, L. (1990), "Narrative as a paradigm for career research", in Young, R.A. and Borgen, W.A. (Eds), Methodological Approaches to the Study of Career, Praeger, New York, NY, pp. 71-86.

Collins, M., Healy, S. and Reynolds, B. (2010), An Agenda for a New Ireland: Policies to Ensure Economic Development, Social Equity and Sustainability, SJI, Dublin.

Connelly, M. and Clandinin, J. (2006), "Narrative inquiry", in Green, J., Camilli, G. and Elmore, P. (Eds), Handbook of Complementary Methods in Education Research, Lawrence Erlbaum, Mahwah, NJ, pp. 477-488.

Davies, B. and Harré, R. (2001), "Positioning: the discursive production of selves", in Wetherell, M., Taylor, S. and Yates, S. (Eds), Discourse Theory and Practice: A Reader, Sage, London, pp. 261-271.

de Koning, J., Mosley, H. and Schmid, G. (2001), "Introduction: active labour market policies, social exclusion and transitional labour markets", in de Koning, J. and Mosley, H. (Eds), Labour Market Policy and Unemployment: Impact and Process Evaluations in Selected European Countries, Edward Elgar, Cheltenham, pp. 1-48.

Denny, K., Harmon, C. and O'Connell, P.J. (2000), Investing in People: The Labour Market Impact of Human Resource Interventions Funded Under the 1994-1999 Community Support Framework in Ireland, ESRI, Dublin.

Department of Finance (2011), "Summary of budget 2012”, available at: http://budget.gov.ie/ Budgets/2012/2012.aspx (accessed 7 August 2012).

Duggan, C. (1999), "Work experience programmes in Ireland: impact and potential”, Poverty and Policy Discussion Paper No. 4, CPA, Dublin.

Emerson, J. (1970), "Behavior in private places: sustaining definitions of reality in gynaecological examinations", in Dreitzel, H.P. (Ed.), Recent Sociology, No. 2, Macmillan, New York, NY, pp. 72-97.

Eräranta, K., Moisander, J. and Pesonen, S. (2009), "Narratives of self and relatedness in eco-communes", European Societies, Vol. 11 No. 3, pp. 347-367.

FÁS (1999), FÁS Annual Reports and Accounts, FÁS, Dublin.

FÁS (2003), FÁS Annual Reports and Accounts, FÁS, Dublin.

FÁS (2007), FÁS Annual Reports and Accounts, FÁS, Dublin.

FÁS (2008), FÁS Annual Reports and Accounts, FÁS, Dublin.

FÁS (2011), FÁS Annual Reports and Accounts, FÁS, Dublin.

Flick, U. (2009), An Introduction to Qualitative Research, 4th ed., Sage, London.

Foucault, M. (1975/1979), Discipline and Punish. The Birth of the Prison, Vintage/Random House, New York, NY.

Foucault, M. (1976/1978), The History of Sexuality, Volume 1, Pantheon, New York, NY.

Foucault, M. (1980), Power/Knowledge: Selected Interviews \& Other Writings, 1972-1977, Pantheon, New York, NY.

Foucault, M. (1982), “The subject and power”, Critical Inquiry, Vol. 8 No. 4, pp. 777-795.

Foucault, M. (1988), The History of Sexuality, Volume 3, The Care of the Self, Random House, New York, NY.

Gabriel, Y. (2004), "Narratives, stories and texts", in Grant, D., Hardy, C., Oswick, C. and Putnam, L. (Eds), The Sage Handbook of Organizational Discourse, Sage, London, pp. 61-78.

Giddens, A. (1991), Modernity and Self Identity: Self and Society in the Late Modern Age, Polity, Cambridge. 
Goodley, D., Lawthom, R., Clough, P. and Moore, M. (2004), Researching Life Stories: Method, Theory and Analyses in a Biographical Age, RoutledgeFalmer, London.

Hill, J. and Halpin, B. (2008), The Role of Active Labour Market Programmes in Employment Policy, Paper No. 10498 University of Munich, Munich.

International Labor Organization (ILO) (1964), Employment Policy Convention (No. 122), ILO, Geneva.

Langellier, K. (1989), "Personal narratives: perspectives on theory and research", Text and Performance Quarterly, Vol. 9 No. 4, pp. 243-276.

Layte, R. and O'Connell, P. (2005), Moving On? The Dynamics of Unemployment in Ireland During the 1990s, CPA, Dublin.

Lewis, J. (1992), "Gender and the development of welfare regimes", Journal of European Social Policy, Vol. 2 No. 3, pp. 59-73.

Lewis, J. (2001), "Legitimizing care work and the issue of gender equality", in Daly, M. (Ed.), Care Work: The Quest for Security, ILO, Geneva, pp. 57-75.

Mills, C.W. (1959), The Sociological Imagination, Penguin, Middlesex.

National Competitiveness Council (NCC) (2010), Annual Competitiveness Report 2009, NCC and Forfás, Dublin.

O'Connell, P. (2002), “Are they working? Market orientation and the effectiveness of active labour market programmes in Ireland”, European Sociological Review, Vol. 18 No. 1, pp. 65-83.

OECD (1964), Recommendations on an Active Manpower Policy, Manpower and Social Affairs Committee, OECD, Paris.

OECD (1993), Active Labour Market Policies: Assessing Macroeconomic and Microeconomic Effects, Employment Outlook, OECD, Paris.

OECD (2000), Policies Towards Full Employment, OECD, Paris.

OECD (2009), Economic Survey of Ireland 2009: The Labour Market: Getting People into Work, OECD, Paris.

Reinharz, S. (1997), "Who am I? The need for a variety of selves in the field”, in Hertz, R. (Ed.), Reflexivity and Voice, Sage, Thousand Oaks, CA, pp. 3-20.

Spicker, P. (2008), Social Policy: Themes and Approaches, Policy Press, Bristol.

Taylor-Gooby, P. (1991), "Welfare state regimes and welfare citizenship”, Journal of Social Policy, Vol. 1 No. 20, pp. 93-105.

Thomas, R. (2009), "Critical management studies on identity - mapping the terrain", in Alvesson, M., Bridgman, T. and Willmott, H. (Eds), The Oxford Handbook of Critical Management Studies, Oxford University Press, Oxford and New York, NY, pp. 166-187.

Thomas, R. and Davies, A. (2005a), "Theorizing the micro-politics of resistance: new public management and managerial identities in the UK public services", Organization Studies, Vol. 26 No. 5, pp. 683-706.

Thomas, R. and Davies, A. (2005b), "What have the feminists done for us? Feminist theory and organizational resistance”, Organization, Vol. 12 No. 5, pp. 711-740.

Thomas, R., Mills, A. and Helm Mills, J. (2004), "Introduction: resisting gender, gendering resistance", in Thomas, R., Mills, A. and Helm Mills, J. (Eds), Identity Politics at Work: Resisting Gender, Gendering Resistance, Routledge, Oxfordshire, pp. 1-19.

Van Maanen, J. (1977), "Experiencing organization: notes on the meaning of careers and socialization”, in Van Maanen, J. (Ed.), Organizational Careers: Some New Perspectives, Wiley, New York, NY, pp. 1-15.

Watson, T.J. (2008), "Managing identity: identity work, personal predicaments and structural circumstances", Organization, Vol. 15 No. 1, pp. 121-143.

Resistance to doing employment

\section{$+$}


$\mathrm{QROM}$

8,2

Weedon, C. (1997), Feminist Practice and Poststructuralist Theory, 2nd ed., Blackwell, Oxford. Weick, K.E. (1995), Sensemaking in Organizations, Sage, Thousand Oaks, CA.

West, C. and Zimmerman, D.H. (1987), "Doing gender”, Gender \& Society, Vol. 1 No. 2, pp. 125-151.

Willis, P. (1977), Learning to Labour: How Working Class Kids Get Working Class Jobs, Gower, Hampshire.

\section{About the author}

Having worked in human resource management and training/education positions in a variety of state, commercial and not-for-profit companies, Sue Mulhall is now lecturing in the Dublin Institute of Technology (DIT). She is a pracademic, combining theory and practice, particularly in the field of career management. Prior to joining DIT to lecture in Human Resource Development and Leadership, she ran her own human resource training, consulting and coaching business for over a decade and previously was a human resource practitioner for 13 years. Her doctorate researched the stories of career success from participants on an active labour market programme in Ireland, called Community Employment. Her current research interests include using narrative inquiry to explore how personal transitions can potentially trigger processes of critical self-reflection, thus having material consequences for a person's evaluation of his or her career experiences. She is also a regular contributor to the Irish broadcast, print and online media on career and management issues. Sue Mulhall can be contacted at: sue.mulhall@dit.ie

To purchase reprints of this article please e-mail: reprints@emeraldinsight.com Or visit our web site for further details: www.emeraldinsight.com/reprints 